\section{Da freguesia de Ossela ao seringal Paraíso: a trajetória de um jovem imigrante português no mundo da borracha amazônica}

\author{
Por Marília Ferreira Emmi \\ Universidade Federal do Pará \\ (mfemmi@ufpa.br)
}

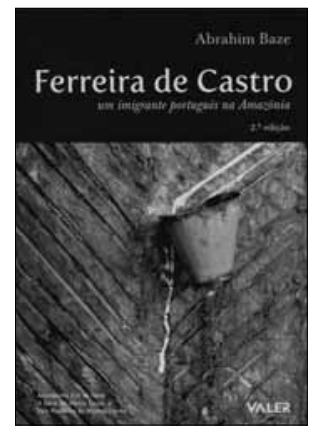

BAZE, Abrahim

Ferreira de Castro: um imigrante português na Amazônia. 2. ed.

Revista e ampliada.

Manaus: Valer, 2010

266 p. il. 1 DVD. ISBN 85-7512-194-4

O livro "Ferreira de Castro: um imigrante português na Amazônia", do escritor amazonense Abrahim Baze, editado pela Valer em 2010, consiste numa edição revista e ampliada da edição que foi lançada em Portugal em 2001. Encontra-se encartado na presente edição um DVD do filme "A Selva", baseado no livro com mesmo título que projetou o escritor português José Maria Ferreira de Castro em nível mundial. Esse filme é dirigido pelo também amazonense Márcio Souza.

Resultado de uma longa e intensa pesquisa realizada em Portugal e na Amazônia, o trabalho constitui uma cuidadosa biografia de Ferreira de Castro, que ainda adolescente chega a Belém em 1911 e, não encontrando ocupação no comércio da cidade, é arregimentado ao lado de trabalhadores nordestinos para o seringal Paraíso, localizado no rio Madeira, estado do Amazonas. Ao biografar Ferreira de Castro, Abrahim Baze usa como pano de fundo o romance "A Selva", que aparece retratado ao longo de sua narrativa. Inicia suas reflexões situando a história da extração da borracha na Amazônia, os personagens, atores sociais dessa particular economia sustentada no sistema de aviamento, que caracterizou o extrativismo amazônico. Esse trabalho permite, ainda, aos que não leram o clássico "A Selva", penetrar no universo da obra de Ferreira de Castro.

As relações de exploração que marcaram o sistema de aviamento são descritas em traços precisos por quem é profundo conhecedor desse sistema, demarcando com acuidade o lugar de cada personagem, elos dessa cadeia de dominação/subordinação. Desse modo, aparecem na narrativa as firmas exportadoras, o seringalista, o guarda-livros, o encarregado e o seringueiro. Também há lugar reservado ao regatão, um componente tão presente nessa trama.

Embora privilegiando em sua narrativa o período compreendido entre 1911 e 1914, que marcou a vida de Ferreira de Castro no seringal, Abrahim faz um recuo histórico desde o nascimento na aldeia de Salgueiros freguesia de Ossela do Conselho de Oliveira de Azeméis - até a vinda para Belém. A decepção do adolescente em não encontrar o tão esperado trabalho no comércio da cidade é o motivo que o leva a ser arregimentado, ao lado de imigrantes nordestinos, para o seringal Paraíso. As agruras da vida no seringal são descritas por diferentes prismas. Abrahim registra, ainda, o regresso a Belém, as dificuldades encontradas nesse regresso e, depois de muitos percalços, a viagem de volta a Portugal.

A saída do jovem José Maria Ferreira de Castro de Portugal se dá no contexto das Grandes Migrações, quando um contingente significativo de europeus de várias nacionalidades atravessa o Atlântico em busca de melhores condições de vida.

A Amazônia, no período áureo da borracha, era o eldorado, um pólo de atração de imigrantes. Zé Maria tem o perfil do imigrante português desse período: jovem com idade inferior a 14 anos, passageiro de $3^{\mathrm{a}}$. classe, que emigrava visando trabalhar com um comerciante português, amealhando recursos que permitissem voltar para sua terra com melhores condições econômicas. Chegando a Belém, não consegue realizar esse sonho e a alternativa que encontra é o trabalho no seringal, local incomum para imigrantes europeus, mas que era o principal destino de migrantes nordestinos.

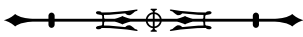


A leitura do livro de Abrahim Baze sugere uma reflexão sobre a economia e sociedade amazônicas do período áureo da borracha aos primeiros anos de crise. Apresenta uma descrição dos atores sociais dessa economia, não apenas por documentos escritos, como também por fotografias. Neste sentido, chama atenção o anexo com fotografias e a reconstituição da história do seringal Paraíso, importantes registros para a preservação da memória.

A interessante narrativa de Abrahim transporta o leitor para o universo amazônico, rico em belezas naturais que contrastam com as difíceis e até desumanas condições de trabalho a que eram submetidos grandes contingentes de seringueiros, cujas vidas davam suporte à concentração de riqueza dos 'barões' da borracha. Ainda fazem parte desse universo, os índios - antigos donos da terra -, que se sentem incomodados com a presença do estranho e reagem; e a riqueza das plantas nativas, que mereceram cuidadosa descrição por parte do autor. Abrahim também deixa registradas interessantes observações sobre as manifestações culturais dos seringueiros nordestinos, que, por meio de festas e folguedos, buscavam uma fuga do trabalho penoso, ao mesmo tempo em que contribuíam para o folclore amazônico.
O trabalho de Abrahim - embora não seja essa a intenção do autor - aborda as diversas fases do processo migratório: a trajetória do jovem José Maria Ferreira de Castro começa como o emigrante que deixa a aldeia de Ossela, em Portugal, passa para a condição de imigrante ao entrar no Brasil e se fixar na Amazônia, e cumprindo esse percurso, retorna a Portugal. Desse modo, a leitura permite visualizar o ciclo completo do movimento migratório: emigração, imigração e retorno. A perspectiva do retorno, ainda que muito diferente das condições idealizadas, é parte integrante do projeto migratório.

Finalizando, considero o livro de Abrahim uma interessante contribuição para todos os que se dedicam a pensar a sociedade e a economia amazônicas do início do século $X X$, bem como para a reflexão sobre as experiências migratórias desse período.

Abrahim Baze é graduado em História e estudioso de Museologia. Foi responsável pela organização do Museu Fernando Ferreira da Cruz, da Beneficente Portuguesa, e do Centro Cultural Luso-Brasileiro do Amazonas. É autor dos livros "Luso Sporting Club - Memória da Sociedade Portuguesa no Amazonas"; "História da Rede Amazônica"; "Real e Benemérita Sociedade Portuguesa Beneficente do Amazonas", entre outros. 